\title{
RISK CONTROL IN PROFESSIONAL LIABILITY INSURANCE
}

$P_{\text {rofessional liability insurance has become society's chief agency for }}$ the distribution of the cost of malpractice by the medical profession. It is quite natural that the medical practitioner, conscious of the possibility of a ruinous malpractice judgment, should seek the protection of insurance. Several factors indicate that this segment of the insurance industry will grow rapidly in the future. ${ }^{1}$ The public is becoming increasingly aware of the possibility of successfully suing its doctors, ${ }^{2}$ the relationship of doctor and patient is becoming increasingly less personal, ${ }^{3}$ and comprehensive studies of the incidence of malpractice litigation disclose that the number of suits is increasing. ${ }^{4}$ Moreover,

\footnotetext{
${ }^{1}$ Only a very small portion of the liability insurance written today is professional liability insurance.

'Silverman, Medicine's Legal Nightmare, The Saturday Evening Post, April I I, $\mathrm{x} 8,25, \mathrm{x} 959, \mathrm{pp} . \mathrm{x} 3,3 \mathrm{r}, 36$.

3 "American doctors are well aware of the restorative effect that their sympathetic interest can have on a patient. But today many people have an image of the modern doctor that is infinitely far from this ideal of medicine. In the place of the kindly, concerned doctor they see a bronzed man in a white coat who sits in his office, cold and bored....
}

-..

The medical profession is frank to admit that some bad blood has welled up recently between patients and physicians, and it is worrying about how to get rid of it. The profession fears that something may be going wrong with American medicine's proudest boast, the warm and wonderful "doctor-patient relationship." Young, Rx: For Modern Medicine Some Sympathy Added to Science, Life, Oct. 12, r959, p. 145.

"Medicine is at a stage of crisis in its relationship with people. . . Only $\mathrm{r}_{5}$ or 20 years ago, medical men in general had an exalted social position. . . During this same period the public has gradually come to understand that these marvelous medical men indeed have feet of clay. Steadily our position of privilege in the eyes of laymen has been reduced. ... O Our privileged status is nearly gone." Ibid.

As early as r 940 the increase in actions for negligence against physicians was attributed to ". . . the gradual disappearance of the family doctor. Traditionally, the family doctor has been the friend and confidant of his patient and has enjoyed a comparative immunity from legal action as a result of this personal relationship. The modern trend toward impersonal efficiency, while it has undoubtedly raised the standards of the profession, has forced the physician's efforts to stand alone in the light of scientific merit, unprotected by the armor of friendship." Note, 26 VA. L. REv. 9 I9 (1940). See also, Nourse, The Changing Role of the Family Doctor, The Saturday Evening Post, Oct. I7, 1959, p. 25.

'Regan, Doctor and Patient and the Law 8, 9 (1959); Opinion Survey on Medical Professional Liability, I64 A.M.A.J. 1583, 1584 (1957). California leads 
jury verdicts in malpractice cases have assumed unprecedented proportions in some jurisdictions. ${ }^{5}$ In response, doctors are purchasing larger amounts of malpractice insurance. ${ }^{6}$

It is not unreasonable to anticipate that the insurance companies will react to these demands upon their resources by continuing to raise premium rates ${ }^{7}$ and by tightening the policy provisions governing the scope of the risk assumed. As a result, conflicts are likely to develop

with 164 cases reported to 1955 . New York is second with $13 x$ reported cases; Ohio third with Ior; and Illinois sixth with 8o. Delaware has no reported cases. Sandor, The History of Professional Liability Stits in the United States, I 63 A.M.A.J. 459, 46I65 (1957). See Belli, Modern Trials 1966 (1954). See also, Note, 26 VA. L. REv. 919 (1940). "One out of every seven doctors sooner or later so dissatisfies at least one of his patients that he is sued for malpractice....

-...

"A nationwide study commissioned by the American Medical Association showed last April that $44 \%$ of all people interviewed have had 'unfavorable experiences' with doctors, $32 \%$ of them so unsatisfactory that they said they would never go back to the same doctor." Young, supra note 3 , at 146.

- A California court recently awarded $\$ 230,000$ because of a faulty treatment of a hip injury, Friedman v. Dresel, I39 Cal. App. 2d 333, 293 P.2d 488 (1956), and $\$ 115,000$ was awarded for malpractice in plastic surgery on the breasts of a fifty-yearold woman, Gluckstein v. Lipsett, 93 Cal. App. 2d 39I, 209 P.2d 98 (1949). See 3 BELLI, op, cit. supra note 4 , at 1999-2002. In United States v. Canon, 2 I 7 F.2d 70 (9th Cir. 1954), an award of $\$ 123,000$ was given for failure to use antibiotics known to the surgeon in post-operative care of a varicose-veins victim. Cases are collected by Sandor, supra note 4 , at 464 . It has been pointed out, however, that the cost of malpractice suits is less than one per cent of the nation's medical bill. Silverman, supra note 2 , at 48 .

A random sampling of 7,577 AMA members produced 5,34I replies to a welldrafted questionnaire. The survey reports that $92.3 \%$ of all physicians are covered by some form of professional liability insurance. Opinion Survey on Medical Professional Liability, I64 A.M.A.J. 1583,1590 (1957). The average (median) coverage for general practitioners in 1957 was $\$ 25,000$ (for the claims of any one person) and $\$ 75,000$ (total liability during the policy period). For surgeons and other specialists, the average coverage is $\$ 100,000$ and $\$ 300,000$. "Now only the most foolhardy physician would dare practice without insurance protecting him against judgments of $\$$ roo,ooo and certain specialists carry as much as $\$ 300,000$ or even $\$ 500,000 . "$ Silverman, supra note 2 , at 15 .

7 The premium rates reflect the amount of malpractice litigation and the size of recent verdicts in the particular area. In 1952 the cost of a $\$ 5,000 / \$ 15,000$ policy to a physician in New York City was $\$ 106.32$, while in upstate New York the same policy cost $\$ 63.96$. 53 N.Y.J. MED. 1003 (1953). Current premium rates in the New York metropolitan area are $\$ 170$ and in California $\$ 228$. "The premiums . . . have increased steadily during the past decade, sometimes jumping by as much as roo per cent or more in one year, and now may cost a doctor $\$ 400$ to $\$ 600$ a year -and even higher for such high-risk specialties as certain types of surgery, radiology and anesthesiology." Silverman, supra note 2, at 48 . Professional liability insurance premium rates are, of course, subject to regulation by the states. See PatTerson, The Insurance CommisSIONER IN THE UNITED STATES (1927). 
which may lead to an increased volume of litigation regarding the traditional risk-control devices employed in professional liability insurance.

The professional liability insurer must accurately delimit the scope of the risk assumed if the cost of malpractice is to be justly distributed among the members of the insured group in proportion to the risks to which they expose the common funds. Risk-control devices are thus a prime concern of the insurance industry. Insurance underwriters seek to control the risk by the wording of the insurance contract and by the careful selection of those whom they will insure.

\section{"Malpractice, Error, or Mistake"}

The provision most commonly used to define the scope of the risk assumed by the professional liability insurer is "malpractice, error, or mistake . . . in the practice of insured's profession." Defining the activity from which the liability of the insured arises is basic to all liability insurance. Before there can be any duty of performance of the insurer's promise to defend or indemnify, the insured must have incurred a possible liability for medical malpractice.

The origins of the physician's legal obligation to his patient may be traced from the Code of Hammurabi, through both Canon and Roman law, ${ }^{9}$ to the rule laid down by Fitzherbert in 1534, that, "it is the duty of every artificer to exercise his art right and truly as he ought."10 Everad v. Hopkins ${ }^{11}$ is probably the first recorded case of medical malpractice in England. In this case, Coke said that the physician could be sued for negligence regardless of any contractual obligation. By 1807 , the law of medical malpractice had so taken on the character of tort law that an English court held that if a physician is licensed, he is liable for exercising less than an ordinary degree of skill although he gives his services gratuitously and without promising a cure. The court

${ }^{8}$ The insuring agreement usually provides: "The Company agrees with the insured in consideration of the premium and in reliance upon the statements in the declarations and subject to the limits of liability, exclusions and conditions .... to pay on behalf of the insured all sums which the insured shall become legally obligated to pay as damages because of injury arising out of malpractice, error or mistake in rendering or failing to render professional services in the practice of the insured's profession. ..." North River Insurance Company, Form No. $\mathrm{L}_{4} 007 \mathrm{~J}$.

${ }_{3}$ BeLLI, op. cit. supra note 4, at x975-76. Note, 26 VA. L. Rev. 919, 920 (1940).

${ }^{10}$ Totell, Natura Brevium (1553), qnoted in Sandor, supra note 4. See also, Slater v. Baker, 2 Wils. 359,362 , 95 Eng. Rep. $860,862-63$ (K.B. 1767).

${ }_{11} 2$ Bulst. 332, 80 Eng. Rep. I 164 (K.B. 1650). 
reasoned that his license implies professional skill. ${ }^{12}$ In I832, Tindal wrote: ${ }^{13}$

Every person who enters into a learned profession undertakes to bring to it the exercise of a reasonable degree of care and skill; he does not undertake if he is an attorney that at all events you shall gain your case, nor does a surgeon undertake that he will perform a cure, nor does he undertake to use the highest possible skill. There may be persons who have a higher education and greater advantages and competent degree of skill, and you will not say whether in this case the injury was occasioned by want of such skill in the defendant. The question is, whether this injury must be referred to the want of a proper degree of skill and care in the defendant or not.

The law also came to recognize that juries would often lack the technical knowledge necessary to judge the medical skill exercised by the doctor, and the expert-testimony rule was evolved to protect the physician from hostile juries by requiring the plaintiff to introduce testimony of another doctor that the defendant did not exercise the requisite care or skill. ${ }^{14}$

While he is not an insurer of the health of his patient and does not guarantee the success of an operation, the doctor's failure to exercise a skill comparable to that of other physicians in the community will subject him to liability. ${ }^{15}$ Doctors are also sued for professional misconduct on theories other than negligence. Patients have successfully sued their doctors for interference with family relationships ${ }^{16}$ and assault and

\footnotetext{
${ }^{13}$ Seare v. Prentice, 8 East. 348, 103 Eng. Rep. 376 (K.B. I 807 ).

${ }^{13}$ Sandor, supra note 4 , at 460 .

${ }^{14}$ Ewing v. Goode, 78 Fed. 442 (S.D. Ohio I897); Adkins v. Ropp, ro5 Ind. App. $33 \mathrm{I}, 14$ N.E.2d 727 (1938). Although frequently criticized as overly protective of the physician, the rule is firmly established. Thus, the jury determines what is malpractice, guided by what the expert witness feels is professional activity below the professional standards of the particular community. Smith v. American Cystoscope Makers, Inc., 44 Wash. 2d 202, 266 P.2d 792 (1954). The principal exception to this rule is that expert testimony is not required when negligence is so apparent that a layman can easily recognize it. Ibid. The doctrine of res ipsa loquitur has also modified the rule in some jurisdictions. Ybarra v. Spangard, 25 Cal. 2d 486, 154 P.2d 687 (r944). Cases in which res ipsa loquitur was invoked in malpractice actions are collected in Annots., 152 A.L.R. 638 (1944), 162 A.L.R. 1265 (1946). Doctors are especially alarmed by suits brought on charges other than negligence, as the expert testimony rule does not then apply. Sandor, supra note 4 , at 466 .

${ }^{15}$ Fritz v. Horsfall, 24 Wash. 2d 14, 163 P.2d 148 (1945).

${ }^{10}$ Milde v. Leigh, 75 N.D. 418,28 N.W.2d 530 (1947). The court held that a husband's cause of action for the defendant-physician's failure to render his wife sterile was not barred by the statute of limitations governing "malpractice" actions. Id. at 432,28 N.W.2d at 538 .
} 
battery. ${ }^{17}$ In one case, a surgeon told his patient he had removed her gall-bladder, when in fact he had not, and she recovered substantial damages for fraud and deceit. ${ }^{18}$ Another patient sued her physician for false imprisonment and recovered damages for the time she spent in an insane asylum. ${ }^{19}$ Still another patient recovered for an invasion of her right of privacy because her doctor permitted a surgical supplyhouse salesman to use an electrical instrument on her person. ${ }^{20}$

It is doubtful that the standard policy covers all of the theories of liability traditionally considered as medical malpractice; therefore, the cautious practitioner should seek more specific coverage. ${ }^{21}$

The important words "malpractice, error, or mistake" have received extensive judicial interpretation. These terms were examined in a recent case ${ }^{22}$ against an insurance company ${ }^{23}$ in which the court held that coverage for "malpractice" included the situation in which an operation was performed without the consent of the patient.

Although some policies specifically insure the physician against liability for breach of contract, ${ }^{24}$ an insured physician who pays damages for breach of contract should not otherwise expect indemnification under "malpractice, error, or mistake" coverage. In the case of Hirsh $v$. Safian, ${ }^{25}$ a patient received a substantial settlement from a plastic surgeon when he failed in his promise to remove markings from the patient's face. When the doctor sought reimbursement, his insurance carrier successfully contended that the settlement had grown out of a breach of a contract to cure. ${ }^{26}$ The court reasoned that because medicine is not an exact science, the honorable practitioner does not warrant a cure, but "undertakes only to give his best judgment and skill," and,

\footnotetext{
${ }^{17}$ Schloendorff v. Society of the N.Y. Hosp., 211 N.Y. 125, 105 N.E. 92 (1914). See Annots., 4 A.L.R. I531 (I919), 76 A.L.R. 562 (1932), 139 A.L.R. I370 (I942). Restatement, TORTS $\$ 54$ (1934).

${ }^{18}$ Moses v. Miller, 202 Okla. 605, 216 P.2d 979 (1950).

${ }^{10}$ Hough v. Ogden, 4 N.J. Misc. 455,133 Atl. 73 (1926).

${ }^{20}$ Carr v. Schifflette, 82 F.2d 874 (D.C. Cir. I936).

${ }^{21}$ The Law Division of the American Medical Association recently sent a questionnaire to the principal companies writing medical liability insurance. The returns indicate a wide difference in the interpretation of many of the provisions of coverage in the standard policy. Hirsh, Insuring Against Medical Professional Liability, 12 VAND. L. REv. 667, 680-93 (1959).

${ }_{22}$ Shehee v. Aetna Cas. \& Sur. Co., I22 F. Supp. I (W.D. La. 1954).

${ }^{28}$ LA. REv. STAT. $\S 22: 655$ (1950), provides for direct actions against the insurer.

24 ACKERMAN, INSURANCE 285 (2d ed. 1938).

25257 App. Div. 212, I2 N.Y.S.2d 568 (1939). See Safian v. Aetna Life Ins, Co., 260 App. Div. 765, 24 N.Y.S.2d 92 (I940).

${ }^{26}$ McGee v. United States Fid. \& Guar. Co., 53 F.2d 953 (Ist Cir. 1931), interpreting Hawkins v. McGee, 84 N.H. 114, 146 Atl. 64 I (1929).
} 
to allow the doctor to recover would afford protection to "medical charlatans. ${ }^{327}$

The earlier case of McGee v. United States Fid. E Guar. $C o .^{28}$ had clearly distinguished liability resulting from "malpractice, error, or mistake" from liability for breach of "special contract." A dissenter in the Safian case argued that, although the doctor's conduct was not "malpractice," it was "error or mistake" in the practice of his profession. ${ }^{29}$ He relied upon Sutherland v. Fid. E Cas. Co. of New York, ${ }^{30}$ which held for the insured on an almost identical indemnity clause. In that case, the fact that the insured had made a special contract did not affect the policy as it was a contract made in the proper practice of his profession. Such a result seems unlikely under the Standard Physicians', Surgeons' and Dentists' Professional Liability Policy, which provides that the policy does not apply to: ${ }^{31}$

... liability of others assumed by the insured under any contract or agreement, or to liability assumed by the insured under any agreement guaranteeing the result of any treatment.

Thus, although the Safian case treats the problem as one of interpreting the terms "malpractice, error or mistake," the standard policy resolves the problem by an "exclusion." 32

Another group of cases makes it clear that the protection afforded by the standard policy does not extend to endeavors outside the lawful and proper scope of the insured's professional activity. Aside from being founded upon "malpractice, error or mistake," the insured's liability must also arise from "rendering or failing to render professional services in the practice of the insured's profession. ${ }^{333}$ The doctor cannot expect his professional liability policy to protect him from liability for negligence in nonprofessional activity. The policy does not protect him as a public official, and it cannot serve as his bond. Thus, although one policy covered "autopsies and inquests," the court properly denied

${ }^{27}$ Safian v. Aetna Life Ins. Co., 260 App. Div. 765, 24 N.Y.S.2d 92 (1940).

${ }^{28} 53$ F.2d 953 (Ist Cir. 193I).

${ }^{20}$ That the endorsement "malpractice, error, negligence or mistake committed in the performance or omission of professional services" covers more than simply "malpractice," is evidenced by Harris v. Fireman's Fund Indem. Co., 42 Wash. 2d 655, 659, 257 P.2d 221, 224 (1953); Sutherland v. Fid. \& Cas. Co., 103 Wash. 583, 175 Pac. 187 (1918).

${ }_{80}{ }_{103}$ Wash. 583,175 Pac. 187 (1918).

${ }^{31}$ Aetna Casualty and Surety Co., Form No. C-2206-2; North River Insurance Co., Form No. L4007J; Commercial Insurance Co., Form No. PL ro4 44.

${ }^{32}$ Patterson, Cases on Insurance 39 (3rd ed. x955). See p. 144 infra.

${ }^{58}$ North River Insurance Co., Form No. L4007J. 
reimbursement for damages incurred by the insured in his capacity as coroner when he directed that an unlawful autopsy be performed. The court recognized, however, that if the doctor had performed the autopsy, he would have been insured against suits based on "malpractice, error or mistake."334

The case of Maier v. United States Fid. E Guar. Co., ${ }^{85}$ held that the activity causing the liability must be closely related to professional services to come within the standard coverage. In this case, a doctor stated in the margin of a death certificate that the deceased died from criminal neglect in a sanitarium, and published a photostatic copy of the certificate in a newspaper. The sanitarium sued the doctor for libel. The court held that liability for the statement in the death certificate was covered by the terms of the policy, but that the newspaper publication was unrelated to professional services. Thus, the insurance company was not obligated to reimbuse the doctor for the expense incurred defending the libel action for the newspaper publication. ${ }^{36}$

The doctor is legally accountable for injuries which result from the "professional services" of his assistants. The standard policy provides limited protection against this type of liability. ${ }^{37}$ The assistant must be qualified and licensed as required by law. ${ }^{38}$ One case held that a "tubber" in a hotel bath-house was not one who renders "professional services."39 In another case, an optometrist injured a patient's eye in attempting to remove dust particles with a surgical instrument. His optometrist's license did not permit such activity because Ohio's statutory definition of optometry clearly did not include removal of foreign substances from eyes. $\mathrm{He}$ unsuccessfully relied upon his insurer's promise to indemnify him against loss from professional malpractice. The court rejected the contention that this was "error or mistake," rather than malpractice, because it felt that the "professional services"

\footnotetext{
${ }^{34}$ Crenshaw v. United States Fid. \& Guar. Co., 193 S.W.2d 343 (Mo. App. 1946).

${ }^{35}{ }_{133}$ Colo. 571, 298 P.2d 391 (1956).

${ }^{38}$ The AMA has warned its members that the standard malpractice policy does not protect them against liability for libel or slander and does not obligate the insurer to offer legal assistance. Alper, Expressing Opinions as to Former Treatments, I6 3 A.M.A.J. 554,556 (1957).

${ }_{37}$ Forms are cited at note 31 supra.

${ }^{38}$ Glesby v. Hartford Acc. \& Indem. Co., 6 Cal. App. 2d 89, 44 P.2d 365 (1935).

${ }^{30}$ Maryland Cas. Co. v. Crazy Water Co., 160 S.W.2d 102, 105 (Tex. Civ. App. x 942 ). The "tubber" who attended the injured woman was paid only $\$ 1.60$ a day, although she followed "the directions in a doctor's prescription in giving a bath.", Id. at ro4.
} 
clause in the policy confined its coverage to optometry. ${ }^{40}$ The policy stated that it did not apply:

... where it shall have been legally established that the damage was caused by an assured while under the influence of intoxicants or narcotics or while engaged in or in consequence of the performance of a criminal act.

Most policies now contain a similar exclusionary clause. ${ }^{41}$ While these clauses may contemplate such acts as criminal abortion, the courts might find that acts outside the scope of the insured's license are "criminal acts," and thereby narrow the scope of coverage.

Professional liability policies are subject to the familiar rule that ambiguous language in an insurance policy will be construed most favorably to the insured. ${ }^{42}$ Liberal interpretation of the terms of coverage enabled a chiropodist to recover from his insurer when he was sued by a patient who fell as she attempted to seat herself in a hydraulic treatment chair which rotated suddenly because it was not "locked." The court held that the injury "arose out of the practice of the insured's profession," which brought it within the coverage of the policy. Maintaining the chair in a proper and safe condition for patients was directly connected with the practice of chiropody. The court said: $:^{43}$

The policy is entitled "Professional Liability Policy" and nowhere in the quoted language relied on is the liability of the insurer restricted to "malpractice." Nor by the wording of the policy is liability thereunder confined to a failure on the part of the insured to exercise that standard of professional skill in the treatment of patients prescribed by law.

The case also points up the necessity of determining whether the relationship of patient and doctor is established, as unless this relationship has been assumed, ${ }^{44}$ the doctor is not entitled to protection under his professional liability policy. ${ }^{45}$

${ }^{20}$ Kime v. Aetna Cas. \& Sur. Co., 66 Ohio App. 277, 33 N.E.2d roo8 (r940). See note 49 infra.

"II Forms are cited at note 3 I supra.

"2 See, e.g., American Alliance Ins. Co. v. Keleket X-Ray Corp., 248 F.2d 920 (6th Cir. 1957); Pennsylvania R.R. v. Travelers Ins. Co., 226 F.2d 520 (6th Cir. 1955); Safian v. Aetna Life Ins. Co., 260 App. Div. 765, 24 N.Y.S.2d 92 (1940); Kime v. Aetna Cas. \& Sur. Co., 66 Ohio App. 277, 33 N.E.2d 1008 (1940). This rule of strict construction has been called "the hallmark of a 'contract of adhesion,' of which insurance is the classic example." Schultz, The Special Nature of the Insurance Contract, I 5 LAW \& Contemp. Prob. 376, 379 (1950). (1952).

${ }^{43}$ American Policyholders Ins. Co. v. Michota, 156 Ohio St. 578, 103 N.E.2d 817

"See generally, 3 BELLr, op. cit. supra note 4, at 2005-06.

"5 In Harris v. Fireman's Fund Indem. Co., 42 Wash. 2d 655, 257 P.2d 221 (1953), 


\section{ExcLusions}

The insurer also controls the risk by exclusions which preclude reimbursement of the insured when his liability arises from specified "events which would otherwise fall, or which might be thought to fall, within the scope of the specified" coverage. ${ }^{40}$ The standard policy excludes liability from the "use of x-ray apparatus for therapeutic treatment unless specifically declared" in the policy. Besides the exclusion for criminal acts and liability caused by one under the influence of narcotics or liquor, most professional liability policies contain an exclusionary clause which provides that the insured is not protected from liability as the "proprietor, superintendent or executive officer of any hospital, sanatorium, clinic with bed and board facilities, laboratory or business enterprise." ${ }^{\prime 47}$ Liability must result from the insured's activities as a doctor, not as a public official, supervisor, or businessman, if he is to be covered by the standard policy.

\section{REPRESENTATIONS AND WaRRANTIES}

The insurer also limits its potential liability by selecting the risks it will assume. Selection of those to whom the insurer will offer insurance necessarily occurs before the insurance contract is signed and the contractual obligations assumed. The insurer may determine that only licensed physicians will be insured and that chiropractors will not be, or it may decide that it will insure optometrists but not chiropodists.

When deciding whether to assume the risk, the insurer may rely upon information provided by the applicant. Statements by the applicant "to give information to the insurer, and otherwise induce him to enter into the insurance contract" are representations. ${ }^{48}$ If the information is material to the risk, and is erroneous, the insurer may be able to avoid the policy. This is usually true even though the misrepresentation was innocently made, for it "deceives the insurer who relies upon it and thus the risk which he actually assumes is different from the one

it was held that an injury suffered by a patient of an osteopath, when the treatment table upon which she was lying collapsed because of a defective safety catch, comes within the terms "any malpractice, error, negligence or mistake committed by any person in the performance or omission of professional services." See also two cases involving the meaning of "professional services" in policies written for beauty salons. Ruggieri v. New Amsterdam Cas. Co., 276 App. Div. 1031, 95 N.Y.S.2d 832 (1950) (memorandum decision); Knorr v. Commercial Cas. Ins. Co., 171 Pa. Super. 488, 90 A.2d 387 (1952).

15 Patterson, op. cit. supra note 32.

17 Forms are cited at note 31 supra.

${ }^{18}$ VANCE, INSURANCE 386 (3rd ed. 1951). 
which the action of the applicant in making the representation led him to suppose he was assuming." 49 A statement that the doctor is a member of a professional society is a representation. ${ }^{50}$

The doctrine of "concealment" is employed by insurers as a last resort when their more conventional means of selection and control of risk have failed to enable them to avoid the contract of insurance and

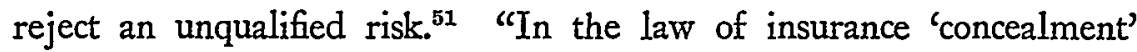
means the mere failure of the applicant for insurance to communicate to the insurer his knowledge of a material fact that the insurer does not know." Concealing a fact that should have been disclosed renders the contract voidable at the option of the injured party. ${ }^{53}$ However, no cases have been discovered which deal with this doctrine in professional liability policies.

The insurer may further delimit the scope of the risk by incorporating into the policy certain conditions precedent to his promise to reimburse the insured. These conditions are "warranties" in insurance jargon. Professor Patterson defines a warranty as "a term of the insurance contract which prescribes as a condition of the insurer's promise the existence of a fact which diminishes the probability of the occurrence of an insured event or the non-existence of a fact which increases such probability. "\$54 Warranties were strictly enforced at common law and did not have to be material to the risk to enable the insurer to avoid the policy. The courts were not interested in their reasonableness or the intent of the parties. ${ }^{55}$ Indicative of this attitude is a statement of the Supreme Court of Errors of Connecticut: ${ }^{56}$

It may, indeed, where the explicit language of a warranty is not adopted, be difficult to ascertain, whether, ... the clause was meant to define or limit a

\footnotetext{
${ }^{40}$ Bankers' Life Ins. Co. v. Miller, 100 Md. I, 59 Atl. I I6 (1904).

${ }^{50}$ United States Fid. \& Guar. Co. v. Fridrich, 123 N.J. Eq. 437, 198 Atl. 378 (1938).

"PATterson, op. cit. supra note 32, at 596.

"Patterson, Insurance 445 (1957). Vance states that the "well settled" American rule is that ". . . failure on the part of the insured to disclose any fact, though clearly material, will not void a . . . policy unless such nondisclosure was fraudulent." He also points out that the California statute does not, however, require the insurer to prove fraud in order to rescind. VANCE, op. cit. supra note 48 , at $372-73$. In contract law concealment is defined as "any affirmative act likely to prevent or intended to prevent knowledge of a fact." Restatement, Contracts \$47 I, comment $f$ (1932). In insurance law, however, "concealment" means mere nondisclosure. See REsTATEMENT, Contracts $\$ 472(\mathrm{r})(\mathrm{d})$, comment $d$ (I932).

ss Wood v. Hartford Fire Ins. Co., I 3 Conn. 533, 545 (r840).

s4 Patterson, Cases on Insurance 452 (2d ed. r947).

${ }^{60}$ Wood v. Hartford Fire Ins. Co., 13 Conn. 533, 545 (1840).

to Ibid.
} 
risk; but when this is ascertained, the insured has no right to dispense with it, or substitute in its place another risk, however advantageous to the insurer. No man can be compelled to adopt a better bargain than his own.

It is immaterial whether the non-performance or violation of the warranty, be with, or without, the consent or fault of the insured. Its strict observance is exacted by law; and no reason or necessity will dispense with it.

An early writer on insurance law justified strict compliance with promissory warranties thus: ${ }^{57}$

To say that the underwriter should answer for a loss, notwithstanding the other party has failed in his engagements, would be to make a different rule in this species of contract, from that which subsists in every other; although this of all contracts depends most upon the strictest attention to the purest rules of equity and good faith.

The law of warranties in liability insurance is now confused and uncertain. The common-law rule of strict construction, which was adopted to protect the infant insurance industry, proved unpalatable as the industry grew. It has been said:.58

Under the guise of benevolent interpretation the courts relieved some individual hardships, yet in many instances they served to educate draftsmen who circumvented their interpretations in the next edition of the policy forms. By the use of printed forms the insurer narrowly restricted the area of bargaining about warranties. Resisting these influences were lay jurymen, who poached upon insurance resources as they would upon the public domain, and sporadic legislation which often proved inept or futile. The product of these ingredients is ... confusion.

It is helpful to distinguish between affirmative warranties, which are stipulations that certain facts exist, and promissory or continuing warranties, which are merely material executory terms of the contract. ${ }^{60}$ An affirmative warranty must be fulfilled only at the inception of the risk; a promissory or continuing warranty must be continuously fulfilled thereafter. ${ }^{60}$ A promissory warranty, then, is an agreement that certain acts will or will not be performed, or that certain conditions will exist, through the life of the policy. Failure of the insured to adhere to these warranties allows the insurer to avoid the policy, re-

\footnotetext{
"7 PARK, InsURANCE 422 (6th ed.), quoted in Vance, Warranty in Instrance Law, 20 YALE L.J. 523,532 (IgII).

${ }^{68}$ Patterson, Warranties in Insurance Law, 34 Colum. L. Rev. 595 (1934), Vance, supra note 57 , at 534 .

${ }^{50}$ Vance, supra note 57 , at 532 .

${ }^{60}$ PatTerson, op. cit. supra note 32 , at 495 .
} 
gardless of whether they are material to the risk. To warrant that the insured is a graduate of a certain medical school is an affirmative warranty, while statements that the insured does not perform major surgery, or that the insured "takes an interest in the educational meetings" of certain societies, seem more like promissory warranties. Both types of warranties are, of course, conditions precedent to the insurer's liability. ${ }^{61}$

As early as I9I I, Professor Vance criticized the doctrine of warranty in insurance law. He pointed out that promissory insurance warranties had frequently been classed with ordinary conditions precedent in mercantile contracts. ${ }^{62}$ At this time, he did not object to strict construction of the promissory warranty; his attack was upon its cousin, the affirmative warranty. He contended that, while the underwriter has reason to complain if he is led to assume a risk differing from that he intended to assume, it does not matter to him whether statements descriptive of the risk are within or without the policy, or whether they are labeled "warranties" or not. If the risk is materially different from that described, he ought not to be liable, while if there is no material difference, he ought not to escape payment simply because the shibboleth "warranty" is found in the policy. Professor Vance overlooks, however, the social desirability of a device to allow the insurer to avoid a policy without having to expend time and money proving the materiality of the provision in question and thus be able to offer insurance protection to the public at a lower premium rate.

A continuing warranty was interpreted in Seay v. Georgia Life Ins. Co. ${ }^{63}$ The policy provided protection from liability in consequence of "malpractice, error or mistake" by any assistants "while acting under the assured's instructions." The court held that the policy did not cover the situation where an assistant treated an injured person without any supervision or specific instruction. Dr. Seay was under contract to provide medical care to several hundred mine employees. The court pointed out that, while it was necessary for him to have assistants, the insurance company assumed the risk in reliance upon the professional skill of the insured and was not liable for the acts of a subordinate whose identity was unknown to it. The assistant doctor was acting independently rather than "under the assured's instructions." This clause does not appear in current policies. ${ }^{64}$

\footnotetext{
${ }^{61}$ Vance, supra note 57.

${ }^{82}$ Ibid.

${ }_{132}^{68}$ Tenn. 673, 179 S.W. 312 (1915).

at But see exclusion (b) of Form No. $\mathrm{L}_{4007 \mathrm{~J}}$ of the North River Insurance Co.,
} 
The chief difficulty in these cases is the failure of the courts clearly to distinguish between representations and warranties. Reimbursement has been denied to the insured although his representation regarding his assistants was not material to the risk. The insurer may rely upon the full performance of the insured's duties under the law, said the New Jersey court in denying recovery to a dentist who falsely stated in the insurance application that his assistant was licensed. It did not matter that the assistant was licensed in another state and that the absence of a New Jersey license did not contribute to the malpractice..$^{05}$

In United States Fid. EO Guar. Co. v. Fridrich, the insurer sought: ${ }^{: 0}$

to cancel a "dentist's liability policy" on the ground that the defendant, at the time of the issuance to him or a renewal of an outstanding policy, falsely represented and warranted that he was a member "in good standing" of the New Jersey State Dental Society when, as a matter of fact, he was not such a member. (Emphasis added.)

Dr. Fridrich notified the insurer that a claim for damages had arisen out of a 1936 tooth extraction. The insurer discovered that, at the time of the injury, the insured was not a member "in good standing" in the dental society because he had not paid his dues in 1936. The bylaws of the society provided that members who failed to pay their annual dues would be considered "in poor standing." When he originally applied for the policy in 1934, Dr. Fridrich truthfully stated, "I am a member in good standing of the New Jersey State Dental Society." The policy was renewed twice. At the time of the second renewal, Dr. Fridrich was a member "in poor standing." Although the court agreed that Dr. Fridrich's statement was a representation and not a warranty, the fact that he was a member in good standing in 1934 when the policy was first issued did not render the insurer liable. The court held that his acceptance of the renewal voucher in 1936 was a representation of unchanged status. Since he was not a member "in good standing" at that time, the insurer was allowed to cancel the policy. The courts have usually held in this situation that such representations relate to conditions as they existed when the statement was originally made, unless they expressly or impliedly refer to the future. ${ }^{.7}$

Representations are significant because they are communicated to

which states that the policy does not apply "to liability of others assumed by the Insured under any contract or agreement."

${ }^{\text {Bs }}$ Betts v. Massachusetts Bonding \& Ins. Co., 90 N.J.L. 632, ror Atl. 257 (x9x7).

123 N.J. Eq. 437,198 Atl. 378 (1938).

${ }^{87}$ Id. at $44 \mathrm{x}$, I98 Atl. at $381 ; 7$ APPLEMAN, INSURANCE $\$ 4505$ (1942). 
the insurer and influence its decision to enter into the contract. False statements in applications impose an intolerable burden upon the insurance carrier. The nature of the insurance contract, which calls for indemnification from a common fund in return for the payment of a relatively small premium, deniands that the contract be avoided when the insured naterially misleads the insurer, even when innocently done. $^{68}$ The majority view, however, requires that the insured make the misrepresentation with knowledge of its falsity. ${ }^{69}$ The court was able to satisfy this requirement in the Fridrich case. Prior to 1934, Dr. Fridrich had owned a "nonmember" policy. To take advantage of the lower premium offered to members, he informed the insurance company of his affliation with the dental society. After the insured event occurred, the doctor filed his claim as a "member in good standing." This enabled the court to charge Dr. Fridrich with the necessary "full knowledge of the bylaws, rules and regulations" of the society to hold that he possessed the "intent to deceive" or knowledge of the falsity of his statement. ${ }^{70}$

A majority of the courts refuse to make an immaterial representation fatal to the contract merely because it was intended to deceive. The rationale is that "the purpose in allowing recision is to protect the insurance company against undesirable risks, not to punish the dishonest applicant whose dishonesty has caused no harm." ${ }^{31}$ In these jurisdictions, Dr. Fridrich's statement would have to be material before the legal consequences of a misrepresentation would operate.

The tests [of materiality] vary in different jurisdictions. The probable common law test is: if he had knowledge of the true facts would a reasonably prudent insurer have made this contract. Other jurisdictions use the test of what might this insurer have done. The third test is the New York statutory formulation - with knowledge of the true facts would this insurer have made this contract. ${ }^{72}$

In the Fridrich case, the New Jersey court applied the second, or individual insurer, standard. The United States Fidelity and Guaranty Company had written this policy specifically for members of the dental society. A different policy was provided nonmembers for a premium

${ }^{68}$ VANCE, op. cit. supra note 48 , at 365 .

${ }^{80}$ Metropolitan Ins. Co. v. Burno, 309 Mass. 7, 33 N.E.2d 519 (1941); Harnett, The Doctrine of Concealment: A Remnant in the Law of Insurance, 15 LAW \& CoNTEMP. Prob. 391, 395 (1950).

${ }^{70} \mathrm{Ibid}$.

${ }^{72}$ Ehrenzweig \& Kessler, Illinois Insurance Code, 9 U. CHI. L.R. 209, 216 (1942).

${ }^{72}$ Harnett, supra note 69 , at 396 . 
three dollars higher. The company would not have rejected the renewal had the doctor's true status been known, but would have accepted it for the higher premium. ${ }^{73}$ The court properly gave considerable weight to the higher premiums for nonmembers as evidence that the plaintiff believed members of the society were better risks. ${ }^{74}$ The court also recognized the comparative difficulty of securing expert witnesses for nonmembers of the society.

Because the insured knew he was not a member in good standing, it may be said that his statement was a fraudulent representation of his status. Since the statement was proved material, and not presumed to be so, the court could have avoided possible confusion and difficulty by treating the statement purely as a "representation." Regrettably, however, the court, although calling it a representation, failed to confine its discussion to representations, with the result that the case has been cited for the proposition that when the warranted status of membership does not exist, the consideration for the policy fails. ${ }^{75}$

Despite some loose language to the contrary in the Fridrich decision, if the applicant's statement is a part of the contract and relates to the risk, it becomes a warranty and creates a condition of the insurer's promise. Courts frequently reveal considerable doubt over whether statements in the "declarations" of the typical malpractice policy are representations or warranties. ${ }^{76}$ The policy in the Fridrich case recited that the consideration was, in part, "the statements and agreements in the application for this policy and which are made a part hereof."m7

"This fact may be used to substantiate the argument that "materiality" is not a question of insurance delinquency, as in fraud, but a mere question of insurance economics to be settled by economic considerations. A solution has been proposed which would involve a proportionate-reduction-of-recovery principle to avoid the all-or-nothing situation currently existing. The argument runs that, due to his misdescription of the risk the insured paid only a part of the premium he should have paid, he is entitled to receive only a proportionate share of the recovery.

This principle has been applied in life insurance where the insured misstates his age. Ehrenzweig \& Kessler, supra note 71 at 219.

${ }^{74}$ See Home Ins. Co. v. Currie, 54 F.2d 203 (5th Cir. 1931). See, Patterson, op. cit. supra note 32 , at 524 .

${ }^{76} 7$ APPLEMAN, op. cit. supra note 67 , at $\$ 4504$ and n. $\mathrm{rr}$.

"However, the Supreme Court of Illinois confidently stated that: "There is a well defined difference between a warranty and a representation in the law of insurance. $A$ warranty enters into and is a part of the contract and must be literally true in order to entitle a party to recover upon a policy of insurance, while a representation is not a part of the contract but is an inducement thereto. A representation must relate to a material matter and is only required to be substantially true." Spence v. Central Acc. Ins. Co., 236 Ill. $444,446,86$ N.E. I04, I05 (rgo8).

77 United States Fid. \& Guar. Co. v. Fridrich, r23 N.J. Eq. 437, 439, 198 Atl. 378, 379 (1938). 
Although this clause clearly seems to make the insured's statements warranties, ${ }^{78}$ many other courts have hesitated to make such a finding. Patterson attributes this tendency to blur the distinctions between warranties and representations to several factors, including the "substantial truth" rule, the general movement to discredit the parol evidence rule, and the belief that legal techniques should be "washed in the 'cynical acid" of realism"-that is, the policy should be construed as it would be understood by the common man who would not realize the different legal effect of a statement contained in the application for insurance which is a representation and must be proved material and the same statement in the policy which is a warranty presumed material. ${ }^{79}$

Of course, a policy may be so worded that it is clear the parties intended the status of the insured to be a condition of liability. ${ }^{80}$ The New Jersey court found that both parties "contracted for a certain status."

The Fridrich opinion avoids a very interesting question. It does not determine whether the policy would be suspended while the doctor was in poor standing simply because he did not pay his dues, although he had been a member in good standing when the policy was renewed. ${ }^{82}$ That is, will a court construe the clause regarding membership in the professional society to be a continuing or promissory warranty? While it is clear that it is not promissory in the sense that a breach will enable the insurer to sue the doctor, ${ }^{83}$ the clause may be interpreted to mean that by carelessness in not paying his dues promptly, the doctor may cause his policy to be suspended during his "poor standing." A similar problem is suggested by a statement in the "declarations" of the policy of the Commercial Insurance Company of Newark, New Jersey: ${ }^{84}$

The insured is a member in good standing and takes an interest in the educational meetings of the following local, state or national professional organizations ....

\footnotetext{
${ }^{78}$ Patterson, op. cit. supra note 52 , at 384 .

${ }^{70} I d$. at 404 .

${ }^{80}$ Young v. Life \& Cas. Co., 204 S.C. 386,29 S.E.2d 482 (1944).

${ }^{81}$ United States Fid. \& Guar. Co. v. Fridrich, 123 N.J. Eq. 437, 441, 98 Atl. 378, $380(1938)$.

${ }^{82}$ Id. at 439 , I98 Atl. at 380 .

${ }^{8 s} \mathrm{~A}$ warranty in insurance has never given the insurer a cause of action for breach of the insured's "promise." For this reason Patterson believes such warranties are better labeled "continuing warranties." PATterson, op. cit. supra note 52, at 3 Io; PATTERsoN, op. cit. supra note 32 , at 495 .

${ }^{84}$ Form No. PL 10414 .
} 
Could this be interpreted as a continuing warranty? At least in New Jersey it seems possible that the policy may be void during the lapse of the insured's "good standing" in a professional society. Might the doctor also lose the protection of his insurance by failing to take "an interest in the educational meetings" of his professional societies? If this is a continuing warranty, the materiality of which is irrelevant, a great deal of interesting litigation can be imagined as the insurer sets up this defense to avoid the policy. Because it is easier for the insurer to establish the defense of breach of warranty than the defense of material misrepresentation, the latter is seldom used when the clause may be construed as a warranty.

It seems unlikely, however, that warranties will become a more important risk-control device in the future. Forty-eight years ago, Professor Vance wrote that "the reign of the technical warranty is almost over." 85 He used the insurance warranty as an example of "how a rule, never very good or necessary, may degenerate so as to become positively bad and so injurious to society that the legal process must bring it to an end."

The harsh results which have often flowed from the strict application of the orthodox doctrine of warranties have prompted the courts and legislatures to seek means of avoiding the doctrine. With considerable ingenuity, the courts have "discovered" ambiguities and have proceeded to resolve them in favor of the insured.87 The "substantial compliance" doctrine may also be used, and parol evidence may be introduced to contradict the recital of consideration. The courts of Illinois and other states have been loath to construe statements of the insured as warranties "unless the provisions of the application and policy taken together have left no room for any other construction." 88

Most state legislatures have enacted statutes dealing with warranties in insurance policies. ${ }^{89}$ Perhaps the most common legislative attack

\footnotetext{
${ }^{85}$ Vance, supra note 57.

${ }^{B e}$ Ibid.

${ }^{87}$ However, Professor Patterson warns the insured that: "Interpretation favoring the insured is frequently grounded upon the maxim that, in case of ambiguity or inconsistency in the terms of the contract, that construction will be adopted which is most favorable to the insured. Although judicial ingenuity in discovering ambiguities or inconsistencies has achieved some marvelous feats of benevolent construction, it must not be too trustingly relied upon even where inconsistency appears, and at all events can be circumvented by improvements in drafting policies." Patterson, supra note 58, at 629.

${ }^{8{ }^{\prime}}$ McClary v. Grand Lodge Bhd., 282 I1l. App. 77, 85 (1935).

${ }^{82}$ Sec Patterson, op. cit. suppa note 32 , at $468-7 \mathrm{I}$; 32 Colum. L. REv. 522 (1929). See also, Vance, supra note 57 , at 523.
} 
on warranties is to provide that warranties shall be construed as representations. $^{90}$ The Nebraska statute, for example, attempts to abolish the traditional concept of warranties by providing that a breach shall not defeat recovery unless it exists at the time of, and contributes to, the loss..$^{91}$ These statutes vary a great deal, ${ }^{22}$ and it is necessarily beyond the scope of this paper to examine their nature and effect. Typical, however, is the North Carolina statute, entitled "Statements In Applications Not Warranties": :3 $^{3}$

All statements or descriptions in any application for a policy of insurance, or in the policy itself, sliall be deemed representations and not warranties, and a representation, unless material or fraudulent, will not preclude a recovery on the policy.

The North Carolina Supreme Court has said that the purpose of this statute is to "prevent insurance companies from escaping the payment of honest losses on technicalities and strict construction of contracts." Thus, the law seems to have borne out, to some extent, Professor Vance's prediction of rgr $\mathrm{r}$.

\section{Postevent Conditions}

Professional liability insurance policies commonly require that the insured cooperate with the insurance company in legal proceedings. The "cooperation" clause is properly interpreted as a continuing warranty the breach of which will relieve the insurer of its duty under the policy. ${ }^{95}$ The following "condition" is found in the current policy of the Commercial Insurance Company $:^{86}$

The insured shall cooperate with the company and, upon the company's request, shall attend hearings and trials and shall assist in effecting settlements, securing and giving evidence, obtaining the attendance of witnesses and in the conduct of suits. The insured shall not, except at his own cost, voluntarily make any payment, assume any obligation or incur any expense.

\footnotetext{
${ }^{\circ 0}$ Patterson, op. cit. supra note 32 , at 448 .

${ }^{02}$ NeB. Rev. STAT. $\$ 44-358$ (1952).

o: Patterson, op. cit. supra note 32 , at 448 .

${ }^{03}$ N.C. Gen. STAT. $\$ 58-30$ (1950).

${ }^{04}$ Cottingham v. Maryland Motor Car Ins. Co., 168 N.C. $259,261,84$ S.E. 274, 275 ( 1915$)$. (1928).

Coleman v. New Amsterdam Cas. Co., 247 N.Y. 271,276, x60 N.E. 367,369

${ }^{00}$ Commercial Insurance Company, Form No. PL ro414. See also, Aetna Casualty and Surety Company, Form No. C-2205; North River Insurance Company, Form No. L4007J.
} 
While the insured's refusal to give the company the necessary information to determine if a defense should be prepared clearly allows the insurance company to consider the policy at an end, "co-operation does not mean that the assured is to combine with the insurer to present a sham defense." ${ }^{\text {tor }}$

A provision in the application, incorporated into the policy, that the insured doctor would "attend, assist, and cooperate" in the defense of suits "without charge to the company" has been interpreted to mean only that the doctor will not charge the insurer a witness fee. It does not mean, said the court, that the doctor has to travel at his own expense from Texas to Ohio for the trial. His failure to appear at the trial because he could not pay the rail fare was not a breach of warranty. ${ }^{98}$ The court went on to point out that the injured patient had a potential right to the proceeds of the policy and that the insurance company had to inform him why the doctor did not come to court. Its failure to give the patient an opportunity to procure the presence of the doctor estopped the company to assert the defense of breach of conditions subsequent when sued by the patient. ${ }^{99}$ The insurer further waived this defense by failing to inform the court of the circumstances when its motion for a continuance on the ground of the insured's nonattendance was overruled. ${ }^{100}$

Another condition of the insurer's liability is the requirement in the "cooperation clause" that the physician give notice to the insurer of the malpractice claim. In Aetna Life Ins. Co. v. Walley, ${ }^{101}$ a careless doctor failed to notify his insurance carrier of the claim until late afternoon on the day the trial was commenced. The policy was issued in 1919, the operation was performed in 1920, and the suit was commenced in 1933. The doctor had destroyed the old policy and could not remember which company had issued it. He inade no attempt to ascertain the name of the insurer for over nine months. The court, following less-than-orthodox warranty theory, pointed out that, while some delay in complying with the notification requirement would not permit avoidance of the policy if the insurer was not materially prejudiced thereby, in the instant case, the notice was given too late for the insurer

\footnotetext{
${ }^{87}$ Coleman v. New Amsterdam Cas. Co., 247 N.Y. 27x, 276, 160 N.E. 367, 369 ( 1928$)$.

${ }^{08}$ Medical Protective Co. v. Light, 48 Ohio App. 508, 194 N.E. 446 (1934).

${ }^{09}$ Of course, the injured party has no greater right against the insurance company than the insured. Georgia Cas. Co. v. Boyd, 34 F.2d 116 (gth Cir. 1929).

${ }^{100}$ Medical Protective Co. v. Light, 48 Ohio App. 508, x 94 N.E. 446 (1934).

${ }_{101}^{101} 74$ Miss. 365,164 So. 16 (1935).
} 
adequately to investigate the merits before the trial to determine whether to settle the case or prepare a defense. As a result, the insurer was relieved of its obligation either to defend or reimburse the insured.

A denial of liability on grounds other than failure to notify the insurer of the institution of the suit is a waiver of that defense. There is no waiver, although the defense has been assumed, if the insured immediately disclaims liability upon discovery of the facts. ${ }^{102}$ It is also generally true that postevent conditions, such as notification and cooperation, are less strictly interpreted and enforced than those conditions to be fulfilled beforehand. ${ }^{103}$ This is consistent with the rule of interpreting the words of the policy least favorably to the insurer who chose them. ${ }^{104}$

\section{ConcLusion}

Judges, legislators, and legal commentators are increasingly cognizant of the sui generis nature of the insurance contract and the publicservice role of the insurance industry. The law of insurance has discarded many burdensome technicalities in order that the industry may better serve as an equitable and efficient means of distributing the costs of accident and misfortune.

Because of the greatly increasing incidence of malpractice litigation and the new importance of professional liability insurance, we may reasonably anticipate increased judicial scrutiny of the professional liability insurance contract, with particular emphasis on the risk-control devices employed by the insurer. It is to be hoped that courts and legislatures will bear in mind the special needs of the medical practitioner and his patient, ${ }^{105}$ while allowing this type of liability insurance policy to de-

\footnotetext{
${ }^{102}$ McGee v. United States Fid. \& Guar. Co., 53 F.2d 953 (Ist Cir. 193I).

${ }^{108}$ Patterson, supra note 58 , at 613.

${ }^{10}$ VANCE, op. cit. supra note 48 , at $689-90$; Schultz, supra note 42 , at 380 . This doctrine of strict construction against the company has received some criticism in light of the fact that today the policy provisions are drafted as much by state regulatory agencies as by the companies. Ibid. It has even been argued that, since the provisions are drafted presumably by the state agencies which represent all the policyholders, logically the language should be construed against the imsured. Calhoun, The Liberal Construction of Insurance Contracts, I CoNN. B.J. 49, 50 (1927). "The logic of this argument fails to square with the case results. In the main the courts still reach judgment for plaintiff by construing the standard policies against the company, just as if they were still drafted by the company." Schultz, supra note 42 , at 380 . See also, VANCE, op. cit. supra note 48 , at 691 .

${ }^{106}$ Recognition that settlement of unmeritorious claims may harm the insured's professional reputation has resulted in the provision (unrelated to risk control) found in professional liability policies, which is unique in the liability insurance field, that the
} 
velop into an even more useful social tool, one unencumbered by technicalities but containing clear definitions of coverage.

company will not settle any claims against the insured without his consent. ACKERMAN, op. cit. supra note 24 , at 286 . The policy of the Aetna Casualty and Surety Co., Form No. C-2205, states that the company may make, "with the written consent of the named Insured, such settlement of any claim or suits as the Company deems expedient." (Emphasis added.) 